\title{
Seasonal carbon budget and growth of Laminaria solidungula in the Alaskan High Arctic
}

\author{
Kenneth H. Dunton \& Donald M. Schell
}

Institute of Water Resources, University of Alaska-Fairbanks, Fairbanks, Alaska 99775-1760, USA

\begin{abstract}
Laminaria solidungula is the dominant member of an arctic kelp community subjected annually to 8 mo of darkness under a turbid ice canopy. Seasonal changes in total tissue carbon were measured for 24 sporophytes incubated in situ for 1 yr. Net annual production was calculated from these measurements and compared to carbon fixation rates from in situ ${ }^{14} \mathrm{C}$ uptake experiments. During rapid linear growth, from November to late April, L. solidungula has a carbon deficit. About $25 \%$ of the plant's original carbon content is depleted before photosynthetic production begins at ice breakup in June or early July. Daily rate of carbon loss $\left(0.7 \mu \mathrm{g} \mathrm{mg}^{-1}\right.$ of frond dry weight) is greatest between November and late February, and least $\left(0.2 \mu \mathrm{g} \mathrm{C} \mathrm{mg}^{-1} \mathrm{~d}^{-1}\right)$ between February and late April due to photosynthesis at extremely low light levels. Summer carbon fixation rate measured by ${ }^{14} \mathrm{C}$ uptake experiments was $0.09 \mu \mathrm{g} \mathrm{mg}^{-1} \mathrm{~h}^{-1}$. This rate of production, when extrapolated for the summer openwater period, matched net carbon production for experimental plants grown in situ, with no assimilatory surplus. L. solidungula reallocates stored reserves to produce new frond tissue during ice-covered periods that replaces about $80 \%$ of the previous year's carbon content.
\end{abstract}

\section{INTRODUCTION}

Laminaria spp. depend to varying degrees on stored food reserves for growth when light levels reach an annual minimum during late autumn and early winter. In the Canadian High Arctic, where seaweeds must endure a winter dark period of at least 3 mo, Chapman \& Lindley (1980) found that L. solidungula accumulated carbon reserves (as reflected in both laminarin content and tissue density) during summer when growth rate was lowest. They noted these reserves were subsequently reduced through the winter, presumably to support growth during the low-light period.

Dunton et al. (1982) noted that Laminaria solidungula plants on the north arctic coast of Alaska produced a new blade and completed nearly $90 \%$ of its annual linear growth in darkness under a turbid ice canopy that occluded light completely from late October until June. They found nearly identical seasonal changes in linear growth and tissue density as Chapman \& Lindley (1980), but growth rates, standing crop and productivity were 2 to 4 times lower than the Canadian population (Dunton et al. 1982, Dunton 1984). Carbon flux has not previously been presented for $L$. solidungula.
In northern European waters, reserves of photosynthate accumulated in the frond of Laminaria hyperborea during summer, its period of slow growth, support the formation and growth of a new blade the following spring (Lüning 1971). In contrast, little accumulation of reserve carbohydrate occurs in $L$. digitata, which exhibits rapid, sustained summer growth (Lüning 1979). Johnston et al. (1977) found that laminarin and mannitol are synthesized by $L$. saccharina during summer. But they noted that these photosynthates were unnecessary for winter growth because the carbon fixed during winter matched the plant's energy requirements. Also, these reserves were not available in autumn and winter owing to distal tissue loss.

Only 2 previous studies have specifically addressed seasonal carbon budgets and carbon allocation in Laminaria spp. Hatcher et al. (1977) examined L. longicruris in Nova Scotia and Johnston et al. (1977) worked on L. saccharina in Scotland. Both studies showed that the species had a photosynthetic surplus throughout most of autumn and winter and possessed a large annual assimilatory surplus that was unaccountable by either growth or accumulation of stored material. Both Johnston and Hatcher concluded that this 
surplus, 25 to $35 \%$ of net carbon fixation, was due to extracellular release of dissolved organic matter.

Do kelp populations living in light-limited arctic environments also have an assimilatory surplus? To answer this question for Laminaria solidungula, we constructed an annual carbon budget based on ${ }^{14} \mathrm{C}$ uptake experiments and compared it to weight gains of plants grown in situ. Seasonal visits to the study site permitted clarification as to how $L$. solidungula allocates its limited carbon supply during several months of continuous darkness while simultaneously completing most of its annual linear growth.

\section{METHODS}

Site description. Experiments were conducted at an established study site, Dive Site 11 (DS-11; $\left.70^{\circ} 19.25^{\prime} \mathrm{N}, 147^{\circ} 35.1^{\prime} \mathrm{W}\right)$, in an area known as the Boulder Patch in Stefansson Sound, $20 \mathrm{~km}$ northeast of Prudhoe Bay in the Beaufort Sea off Alaska's north arctic coast (Fig. 1). The Boulder Patch is an area of cobbles and small boulders that covers approximately $20 \mathrm{~km}^{2}$ of seabed in an area otherwise characterised by fine-grained sediments of silty sands or mud. The rocks provide a substratum for a diverse assortment of invertebrates and several species of algae, including the predominant brown alga Laminaria solidungula, which constitutes over $90 \%$ of the brown algal biomass (Dunton et al. 1982). Water depth at DS-11 ranges from 6 to $7 \mathrm{~m}$.

Data were collected at DS-11 for this study in November 1979 and in February, April, August and November of 1980. During ice-covered periods, we

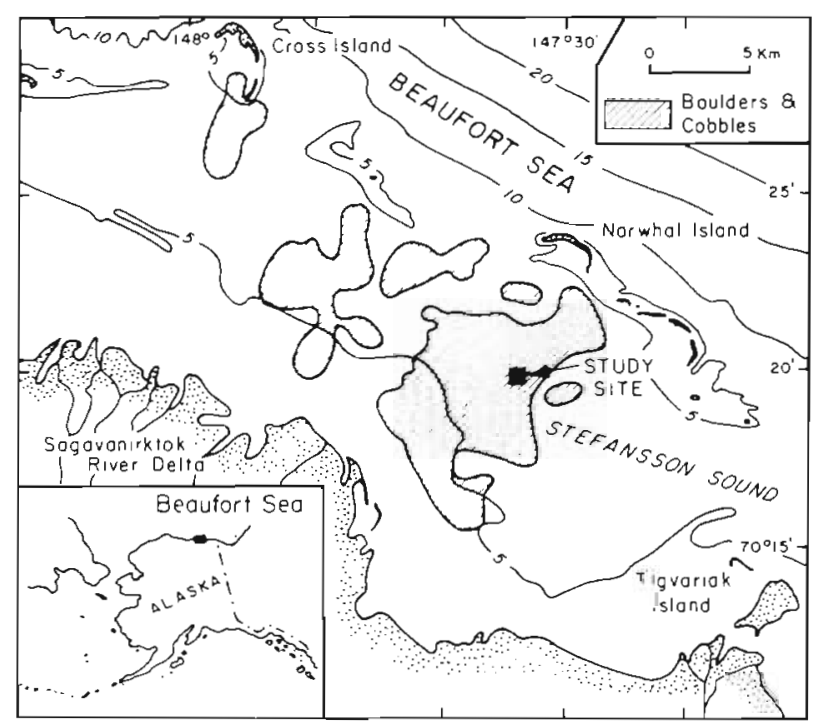

Fig. 1. Location of the study site in the Beaufort Sea, Alaska (from Dunton 1984) entered the water through holes cut in the ice with augers and ice chisels. A heated, insulated hut (Parcoll, Panebee Ltd., Montreal) placed over the dive hole functioned as a dive shelter and laboratory. During the open-water period (early July to late September), we dove from a small boat.

Bottom water temperatures at the site on visits during the ice-covered period were $-1.8^{\circ} \mathrm{C}$. Temperatures ranged from 0 to $3.5^{\circ} \mathrm{C}$ in August.

Field measurements on plants. The frond of Laminaria solidungula is divided into distinct ovate blades of different sizes by constrictions that form annually (Fig. 2). The growth of a new basal blade starts in November and continues until the following November, allowing an accurate measurement of the plant's annual production.

In November 1979, 24 plants were carefully removed from their substratum and brought to the surface. Old blades were removed by slicing the frond at the constriction directly above the basal blade. This elimi-

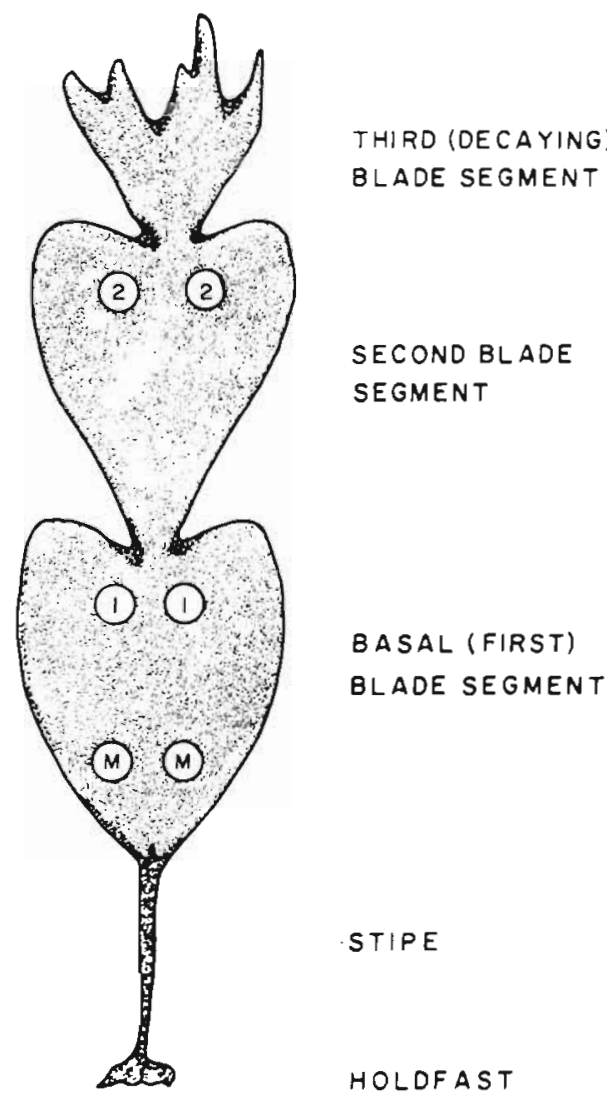

Fig. 2. Laminaria solidungula. Schematic drawing of sampling in a specimen for net production using the ${ }^{14} \mathrm{C}$ method. Open circles mark the samples punched out immediately above the meristematic zone of the growing frond $(M)$, the area of the basal blade segment in which most enlargement of the new blade occurs (1), and the second blade segment left from preceding year (2). Samples were punched out following incubations of entire plants in situ 
nated the problems associated with progressive tissue loss of old, decaying distal blades. We also checked the condition of each plant to ensure it was healthy and that the remaining basal blade was entire and free of epiphytes and grazing scars. Individual plants were measured, weighed to the nearest $0.1 \mathrm{~g}$ on a top loading Mettler balance and the stipes fastened to a large submerged plastic cage anchored to the seafloor. Plants were handled only by their holdfasts. Blades were never blotted, and most excess water was simply removed by allowing the plants to lie on a clean damp towel for about $1 \mathrm{~min}$.

On each subsequent trip to the site, all plants were retrieved, measured, weighed, and then immediately reattached to their support. Plants were discarded if blades or stipes were damaged as a result of natural or artificial causes. To obtain the actual weight of the frond, we subtracted the predicted stipe weight based on a stipe length vs stipe weight regression analysis made from 88 plants collected in November 1979, 1980 and 1981 (Fig. 3). In a separate 1 yr pilot study, we also

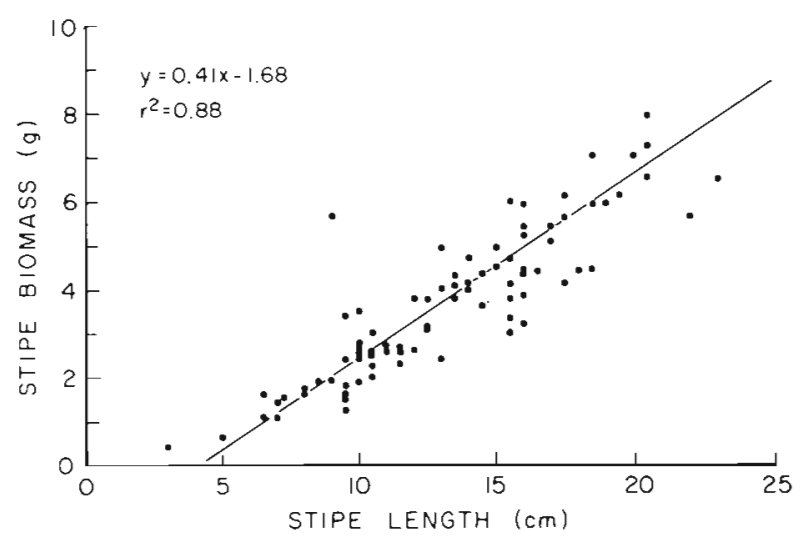

Fig. 3. Laminaria solidungula. Stipe biomass as a function of stipe length $(\mathrm{N}=88$ ). The $95 \% \mathrm{CI}$ (individuals) was \pm 1.72 , the $95 \% \mathrm{CI}$ (mean) was \pm 0.26 found that the net weight gain of an entire plant matched the biomass (wet weight) of the basal blade within $\pm 7 \%$ in nearly all cases with a mean difference of $0.5 \%(\mathrm{~N}=13$; Dunton 1985a). Therefore, for the purposes of estimating carbon budgets, we assumed that the wet weights of the distal blades and stipe remained essentially constant and that all increases in biomass took place in the first blade.

Seasonal changes in average $N$ and $C$ content. On each visit to the site, the basal and second blade segments of 6 to 11 representative plants were taken for analysis of carbon and nitrogen content. Blade segments were separated, dried to a constant weight at $35^{\circ} \mathrm{C}$ and ground to a coarse powder in a mill. Subsamples of ground tissue from each blade were weighed on a Kahn 26 Automatic Electro Balance and analysed for carbon and nitrogen content on a Perkin-Elmer $240 \mathrm{C}$ elemental analyser.

Frond carbon flux. An example of net carbon production for each blade versus the whole frond is shown for a representative plant in Table 1 . The carbon content for each blade was obtained by multiplying the wet weight of the tissue by its density (\% dry weight of wet weight) and carbon content per unit dry weight. Seasonal changes in the tissue density of plants collected at the same time of this experiment have been previously reported (Dunton et al. 1982).

${ }^{14} \mathrm{C}$ uptake. We obtained summer photosynthetic rates of intact mature Laminaria solidungula plants in late July and early August 1980. Each plant was individually enclosed within a $50 \times 30 \mathrm{~cm}$ clear polyethylene bag along with 0.75 to 1.01 of ambient seawater spiked with $5 \mu \mathrm{Ci}$ of $\mathrm{NaH}^{14} \mathrm{CO}_{3}$. The open end of each bag was securely fastened with a large rubber band and electrical tape. The experiment consisted of 4 separate incubations performed over a 5 d period. Each included 4 to 8 experimental plants, 1 to 3 dark-incubated plants and 1 formalin-treated plant. Dark-incubated plants had 3 black polyethylene bags secured

Table 1. Laminaria solidungula. Sample calculation of net carbon loss or gain in new and old tissue in experimental plant No. 3 . All weights in $\mathrm{g}$

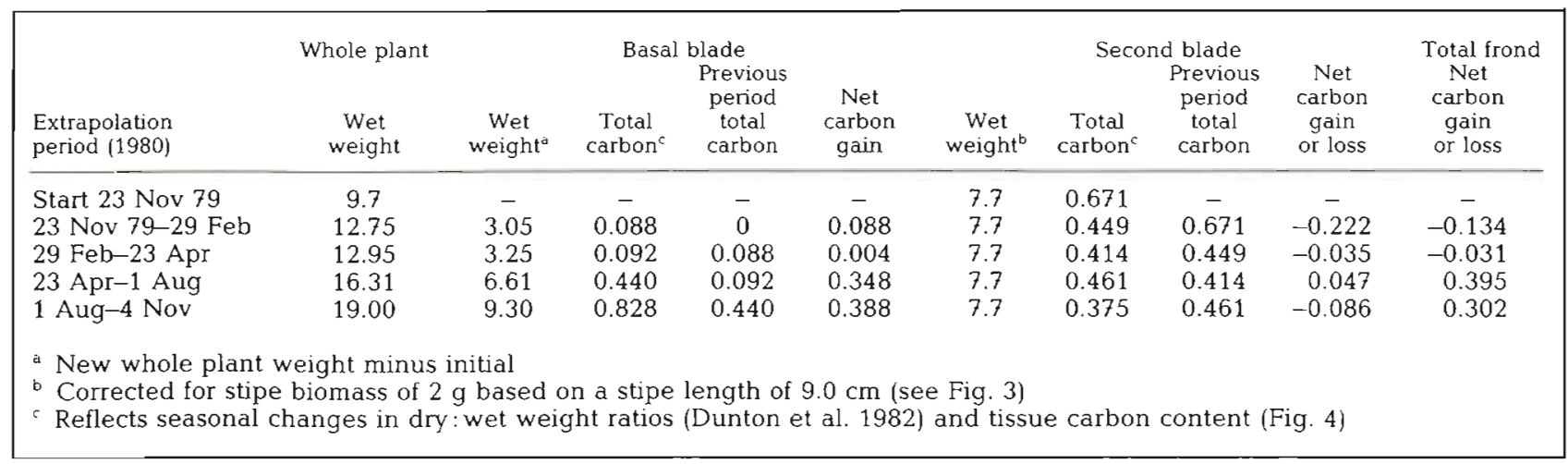


over the clear bags. In situ incubations lasted from 24.5 to $27 \mathrm{~h}$ except for one $18 \mathrm{~h}$ incubation.

After incubation, the plants were removed from their bags, rinsed in seawater, placed in an opaque container, and quickly transported to our field station. Duplicate samples from directly above the meristem, new blade and second blade (Fig. 2) were punched out with a cork-borer (area $0.31 \mathrm{~cm}^{2}$ ) and dried in darkness.

Each ${ }^{14} \mathrm{C}$ labelled disc was weighed in the laboratory, combusted in a biological material oxidizer (Harvey Instrument Corporation), and the ${ }^{14} \mathrm{CO}_{2}$ trapped in a liquid scintillation cocktail. The contents were poured into a scintillation vial and counted for $5 \mathrm{~min}$ on a Beckman LS- $100 \mathrm{C}$ liquid scintillation counter. Background and standard counts were obtained using equivalent amounts of unlabelled kelp discs and quenched ${ }^{14} \mathrm{C}$ standards. We express photosynthetic rates as $\mu \mathrm{g}$ carbon incorporated (mg dry weight) ${ }^{-1} \mathrm{~h}^{-1}$, using a value of $17.4 \mathrm{mg}$ total inorganic- $\mathrm{C}^{-1}$ of seawater (Strickland \& Parsons 1972).

Light measurements. Only instantaneous measurements of in situ illuminance were made. We used a Protomatic underwater photometer (Dexter, Michigan) to obtain total illumination in foot candles. Foot candles (fc) can be converted to $\mu \mathrm{E} \mathrm{m} \mathrm{m}^{-2} \mathrm{~s}^{-1}$ using the conversion $1 \mathrm{fc}=0.21 \mu \mathrm{E} \mathrm{m} \mathrm{m}^{-2} \mathrm{~s}^{-1}$, which assumes a flat spectral irradiance curve over the 400 to $700 \mathrm{~nm}$ range (from LI-COR, Lincoln, Nebraska). During the ice-covered period, we made measurements in November, late February and early March.

\section{RESULTS}

\section{Frond carbon and nitrogen content}

Seasonal changes in total tissue $\mathrm{N}$ and $\mathrm{C}$ content in the developing basal blade and mature second blade are shown in Fig. 4. In both blades, carbon content decreases through the winter, reaching a minimum in late April. Between November and April, the carbon content in Blade 2 dropped from 36 to $31 \%$, which coincided with the formation and rapid growth of the new basal blade segment. From April onward, percent carbon in Blade 2 increased to $32.5 \%$, but did not regain its original carbon percentage. In the basal blade, the carbon content decreased from $29 \%$ in February to $26 \%$ in late April, and then rapidly increased to $37 \%$ by November.

In contrast to carbon, nitrogen content exhibited little distinct seasonal variation in both blades. The nitrogen content in the basal blade dropped steadily through the year while it remained fairly constant (between 1.6 and $1.9 \%$ ) in the second blade. Total

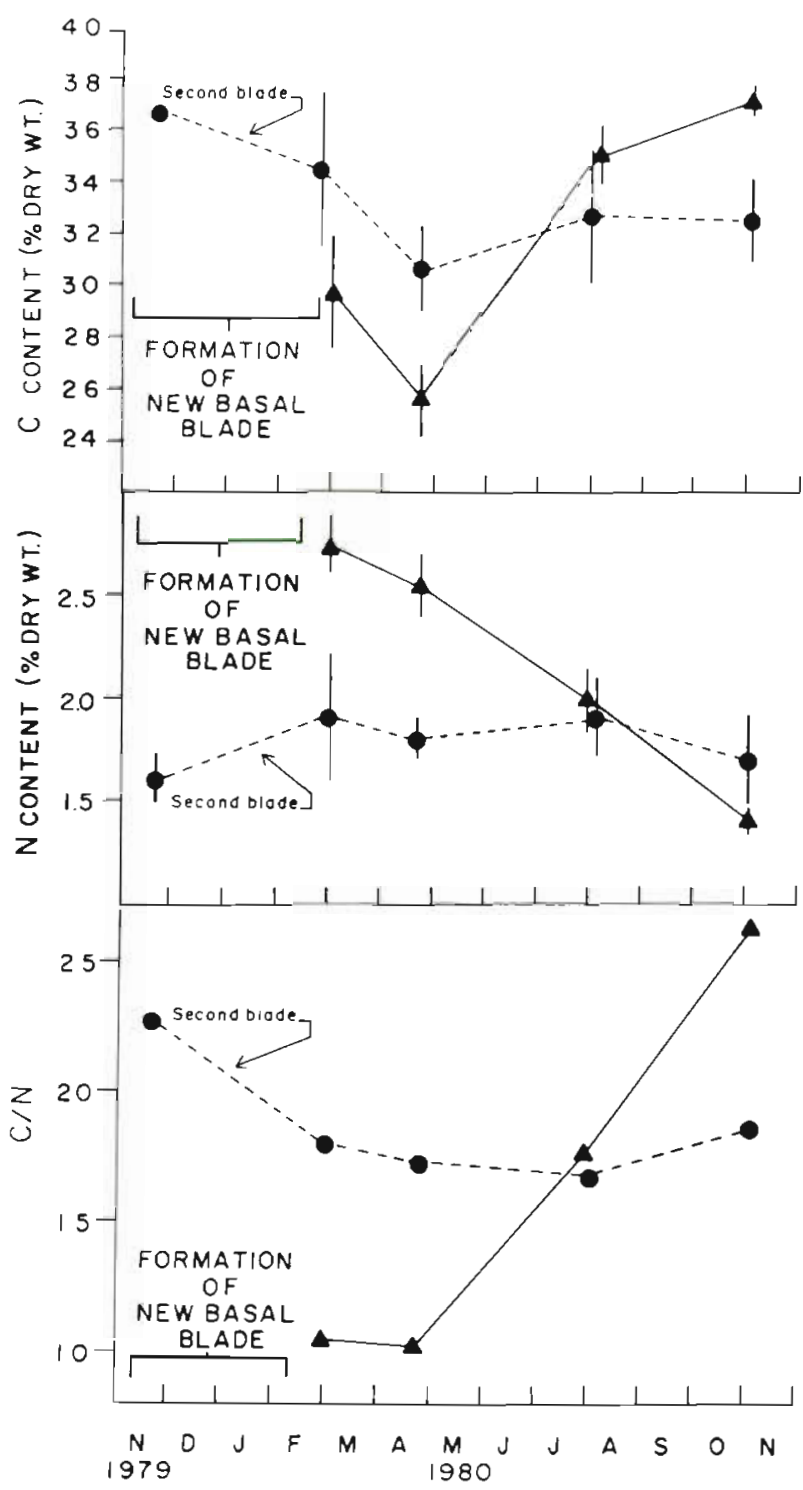

Fig. 4. Laminaria solidungula. Seasonal changes in total carbon, nitrogen (means $\pm 95 \%$ confidence limits) and $\mathrm{C} / \mathrm{N}$ in the first ( $\boldsymbol{\Lambda})$ and second ( ) blade segments of fronds collected at Site DS-11

nitrogen content was significantly lower $(p<0.0001)$ in the second blade than in the basal blade for February and April. In the basal blade, the drop in tissue $\mathrm{N}$ from $2.7 \%$ in February to $1.4 \%$ in November is reflected in its $\mathrm{C} / \mathrm{N}$ ratio which increased from 10 to 26 for the same period. Changes in the $\mathrm{C} / \mathrm{N}$ ratio for the second blade were small, but showed a decrease of 23 to 17 from November to August.

\section{Growth and carbon flux determinations}

A summary of the seasonal pattern of linear growth and tissue carbon flux in the experimental plants in relation to external dissolved inorganic nitrogen con- 
centrations is shown in Fig. 5. Linear growth was high between November and February $\left(0.8 \mathrm{~mm} \mathrm{~d}^{-1}\right)$, the darkest period of the arctic winter. Growth continued to increase until late April, but slowed to $0.6 \mathrm{~mm} \mathrm{~d}^{-1}$ between late April and August. Growth was lowest between August and November $\left(0.1 \mathrm{~mm} \mathrm{~d}^{-1}\right)$, a largely ice-free period.

This seasonal growth pattern agrees well with previous studies on Laminaria solidungula (Chapman \& Lindley 1980, Dunton et al. 1982). A turbid ice canopy occluded light at DS-11, as had been the case in past
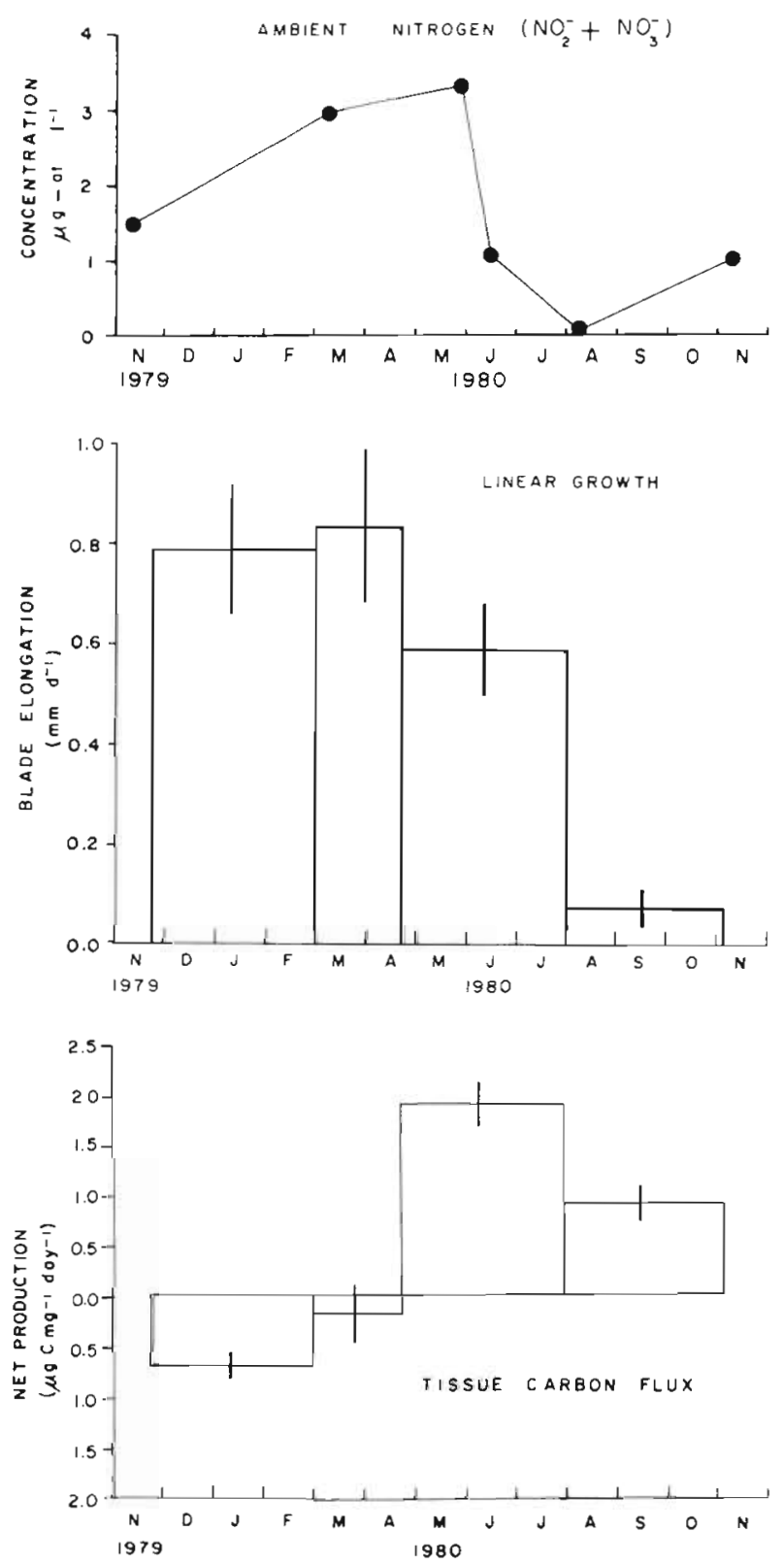

Fig. 5. Laminaria solidungula. Seasonal variation in ambient inorganic nitrogen blade growth (means $\pm 95 \%$ confidence limits) and tissue carbon production at $7 \mathrm{~m}$. Ambient inorganic nitrogen data from Dunton et al. (1982) years (Dunton et al. 1982). Illumination levels on the bottom adjacent to the experimental plants in November and late February ranged from undetectable to 0.16 foot candles (equivalent to less than $0.04 \mu \mathrm{E} \mathrm{m}^{-2} \mathrm{~s}^{-1}$ ). In early March, however, we noticed lighter patches under the ice canopy in several locations that appeared to coincide with our previous activities on the ice surface, which included the removal of ice and snow for dive holes and ice camps. Maximum irradiance under these patches was also low, 0.41 foot candles $\left(0.09 \mu \mathrm{E} \mathrm{m}^{-2} \mathrm{~s}^{-1}\right)$.

Mean net carbon assimilation in the experimental plants showed a pattern nearly inverse to linear growth. Between November and February, net carbon loss in an average sized plant was about $0.7 \mu \mathrm{g}$ $\mathrm{mg}^{-1} \mathrm{~d}^{-1}$. Net carbon loss continued until April, but at a slower pace $\left(0.2 \mu \mathrm{g} \mathrm{mg}^{-1} \mathrm{~d}^{-1}\right)$. The rate of carbon loss decreased during this period because of carbon fixation resulting from patchy light penetration of the ice canopy. A lower respiratory demand during this period is unlikely, since water temperatures remained constant $\left(-1.8^{\circ} \mathrm{C}\right)$, and linear growth rates increased to their highest annual levels.

Net carbon fixation in the experimental plants reached a maximum of $1.9 \mu \mathrm{g} \mathrm{mg}^{-1} \mathrm{~d}^{-1}$ between late April and August. This marks the period of initial ice canopy deterioration, followed by open water in early to mid-July. From August to November, the period of minimum linear growth, net carbon production in the fronds slowed to $0.9 \mu \mathrm{g} \mathrm{mg}^{-1} \mathrm{~d}^{-1}$.

Levels of ambient inorganic nitrogen $\left(\mathrm{NO}_{2}^{-}+\right.$ $\mathrm{NO}_{3}^{-}$) from the same period at DS-11 have been reported previously (Dunton et al. 1982) and are shown in Fig. 5 for comparative purposes. The concentrations of inorganic nitrogen follow an annual cycle typical of arctic waters (Chapman \& Lindley 1980) and temperate waters (Chapman \& Craigie 1977, Wheeler \& North 1981). Inorganic nitrogen concentrations increase from 1.5 to $3.3 \mu \mathrm{g}$-at $\mathrm{l}^{-1}$ from November to June, followed by a sharp decline in mid-June. The winter linear growth of Laminaria solidungula occurs during higher concentrations of inorganic nitrogen as previously reported by both Chapman \& Lindley (1980) and Dunton et al. (1982).

Seasonal variations in frond fresh weight, and the total carbon content of the blades and frond in experimental plant No. 3 are shown in Fig. 6. It is noteworthy that despite a consistent gain in frond fresh weight from November to April ( 7.7 to $11 \mathrm{~g}$ ), the carbon content of the frond dropped from 0.7 to $0.5 \mathrm{~g}$. This loss about $25 \%$ of the initial carbon content of the frond, was typical for most plants. From late April to November, the fresh weight and carbon content of the frond increased. However, the rise in frond carbon content from 0.5 to $1.2 \mathrm{~g}$ was almost entirely due to the 


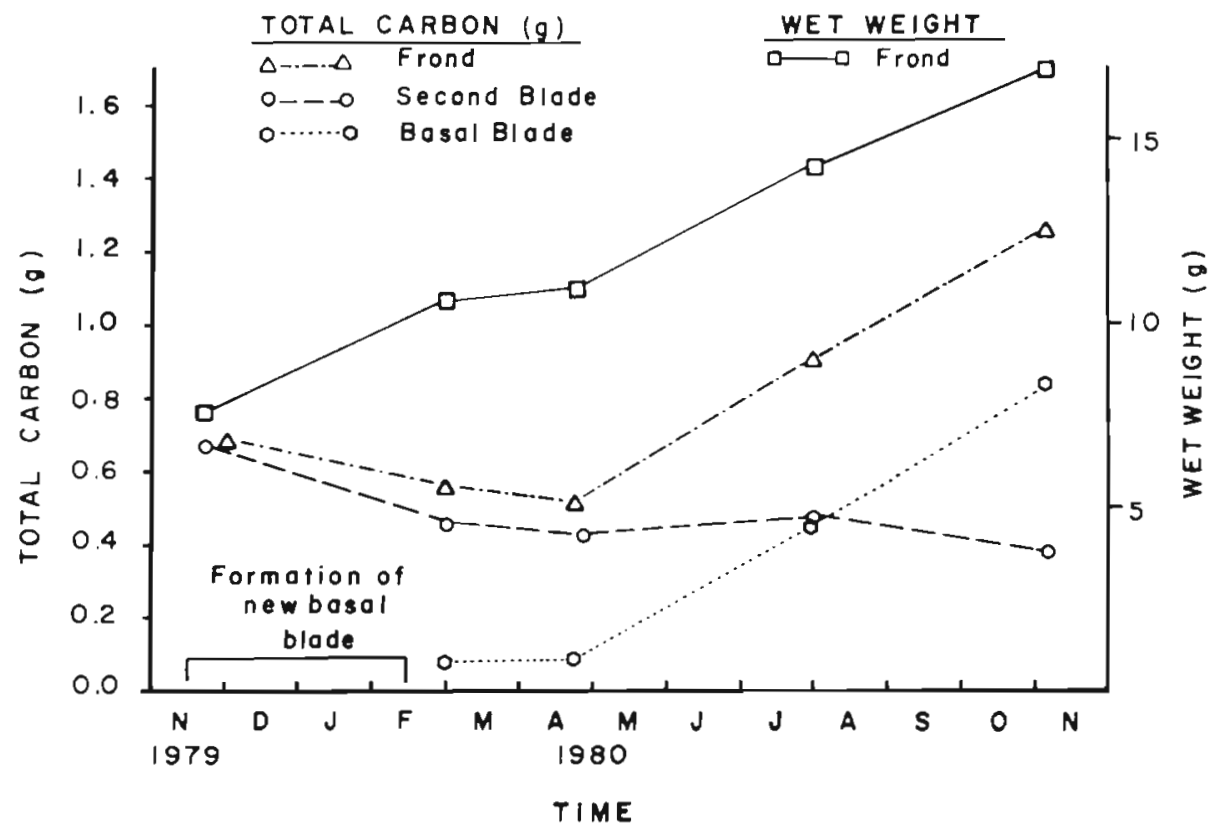

Fig. 6. Laminaria solidungula. Seasonal variation in frond fresh weight, and total carbon content in the basal blade, second blade segment and total frond as exemplified by one of the 14 experimental plants (specimen No. 3) that survived 1 yr fully intact

increase in carbon content of the basal blade. This seasonal variation in fresh weight and carbon content was observed in all the experimental plants.

\section{Annual net photosynthesis: ${ }^{14} \mathrm{C}$ uptake}

Total ${ }^{14} \mathrm{C}$ uptake by Laminaria solidungula during 4 separate incubations from 29 July to 3 August is shown in Table 2. Photosynthetic rates were greatest in the young basal blade above the meristematic region and lowest in the second blade. Light-independent carbon fixation (LICF) was highest directly above the meristematic region, accounting for $16 \%$ of the photosynthetic (PS) rate of $\mathrm{CO}_{2}$ fixation. Over the entire frond, LICF accounted for roughly $13 \%$ of its total capacity for light carboxylation. After correction for LICF, average net photosynthetic fixation in the frond was about $0.09 \mu \mathrm{g}$ (mg dry weight tissue) $)^{-1} \mathrm{~h}^{-1}$.

In situ light measurements made during the 4 incu- bations ranged from nighttime lows of 90 to 130 foot candles (equivalent to about 20 to $30 \mu \mathrm{E} \mathrm{m}^{-2} \mathrm{~s}^{-1}$ ) to daytime highs of 400 to 600 foot candles (equivalent to 80 to $130 \mu \mathrm{E} \mathrm{m}^{-2} \mathrm{~s}^{-1}$ ). Continuous light meter measurements made at a nearby site in early August 1984 reflect photon flux fluence rates of the same magnitude (Table 3). During this $4 \mathrm{~d}$ period, the mean hourly minimum ranged between 40 and $60 \mu \mathrm{E} \mathrm{m}^{-2} \mathrm{~s}^{-1}$, and mean hourly maximums varied between 110 and $210 \mu \mathrm{E} \mathrm{m} \mathrm{m}^{-2} \mathrm{~s}^{-1}$.

\section{Annual carbon budget}

On an annual basis, net carbon production in an average-sized kelp plant is $0.7 \mathrm{~g}$, for an approximate $P$ : $B$ ratio of 0.8 (Table 4 ). This $P: B$ ratio is very close to that reported by Chapman \& Lindley (1981) for this species in Canadian waters. The total carbon gain in new tissue (the entire basal blade) is $1.1 \mathrm{~g}(\mathrm{P}: \mathrm{B}=1.2$ ),

Table 2. Laminaria solidungula. Summary of photosynthetic (PS) and dark fixation (DE) rates (means $\pm 95 \%$ confidence limits) in different regions of the frond based on uptake of ${ }^{14} \mathrm{CO}_{2}$ in 29 plants from 4 separate incubations

\begin{tabular}{|c|c|c|c|c|}
\hline \multirow[b]{2}{*}{ Region } & \multicolumn{4}{|c|}{ Carbon fixation $\left(\mu \mathrm{g} \mathrm{C}[\mathrm{mg} \text { dry weight }]^{-1} \mathrm{~h}^{-1}\right.$ ) } \\
\hline & Photosynthesis & Dark fixation & $\mathrm{PS}-\mathrm{DF}$ & PS : DF \\
\hline Meristem ${ }^{d}$ & $0.093 \pm 0.015$ & $0.015 \pm 0.005$ & 0.078 & 6.2 \\
\hline Basal blade & $0.124 \pm 0.014$ & $0.014 \pm 0.004$ & 0.110 & 8.9 \\
\hline Second blade & $0.082 \pm 0.019$ & $0.011 \pm 0.006$ & 0.071 & 7.4 \\
\hline Whole trond ${ }^{b}$ & 0.100 & 0.013 & 0.086 & 7.5 \\
\hline \multicolumn{5}{|c|}{ Directly above meristematic tissue } \\
\hline
\end{tabular}


Table 3. Summary of light data collected continuously over a 4d period in early August 1984 at a site in the Boulder Patch (data courtesy of Standard Alaska Production Company)

\begin{tabular}{|ccccc|}
\hline $\begin{array}{c}\text { Measurement } \\
\text { date } \\
\text { (Aug 1984) }\end{array}$ & \multicolumn{2}{c|}{$\begin{array}{c}\text { Quantum irradiance }\left(\mu \mathrm{E} \mathrm{m}^{-2} \mathrm{~s}^{-1}\right) \\
\text { Mean hourly } \\
\text { maximum }\end{array}$} & $\begin{array}{c}\text { Mean hourly } \\
\text { minimum }\end{array}$ & $\begin{array}{c}\text { Day } \\
\text { total } \\
\left(\mathrm{E} \mathrm{m}^{-2}\right)\end{array}$ \\
\hline 10 & 208.2 & 59.9 & 121.3 & 10.5 \\
11 & 127.0 & 43.4 & 81.0 & 7.0 \\
12 & 107.8 & 40.1 & 62.7 & 5.4 \\
13 & 118.0 & 44.9 & 66.5 & 5.7 \\
\hline
\end{tabular}

a difference of about $35 \%$. The overestimate of annual carbon production based on basal blade weight alone is explained by the stored food reserves. These reserves are used for both the growth and respiratory requirements of the plant, and are located in the second blade. Therefore, we attribute the difference in annual carbon production to the growth of the new basal blade at the expense of the remainder of the plant. It is difficult to estimate the role of the plant's small kidney-shaped sorus in the carbon budget, because its development in the basal blade segment occurs over a 9 mo period. Development starts in summer and ends with the release of meiospores between February and April.

Based on net annual carbon production in an average-sized plant, and assuming that photosynthesis is minimal during the ice-covered period (November to June), we calculated summer carbon production on an hourly basis. The number of summer hours available for photosynthesis (2264) was calculated by Schell et al. (1984), who used it to estimate phytoplankton productivity in arctic Alaskan nearshore waters. The result, $0.085 \mu \mathrm{g} \mathrm{C}\left(\mathrm{mg}\right.$ dry weight) ${ }^{-1} \mathrm{~h}^{-1}$ (Table 4), closely agrees with the hourly net carbon production estimate found in the ${ }^{14} \mathrm{C}$ uptake experiment (Table 2).

In light of these results, annual net carbon production of a Laminaria solidungula population (standing crop of $140 \mathrm{~g} \mathrm{~m}^{-2}$; Dunton et al. 1982) exposed to a winter turbid ice canopy is about $6 \mathrm{~g} \mathrm{C} \mathrm{m}^{-2}$. This figure is slightly lower than previously reported for L. solidungula in the Boulder Patch (Dunton et al. 1982), since the earlier calculations were based solely on basal blade production. In the absence of turbid ice, productivity climbs to $10 \mathrm{~g} \mathrm{C} \mathrm{m}^{-2} \mathrm{yr}^{-1}$ (Dunton 1984). Therefore, annual production probably lies between 6 and $10 \mathrm{~g} \mathrm{C} \mathrm{m}^{-2}$.

\section{DISCUSSION}

\section{Winter carbon deficit}

It appears that during the 8 mo under a turbid ice canopy, Laminaria solidungula experiences a carbon deficit where up to $30 \%$ of its original total carbon content is depleted. At the same time, however, the plant undergoes rapid linear growth, producing a new blade and completing nearly $90 \%$ of its annual linear growth before the photosynthetic season begins.

During the initial part of the ice-covered period, from November to February, tissue density (a reflection of total tissue carbon) in the second blade drops from 24 to $17 \%$ as stored photosynthate is translocated to the developing basal blade (Dunton et al. 1982). In the subsequent 2 mo, from late February to April, there is little gain in plant wet weight (Fig. 6) and little change in tissue density (Dunton et al. 1982). Yet the plant's carbon deficit continues to accrue as the percent carbon content of dry weight drops significantly $(p<0.01)$

Table 4. Laminaria solidungula. Total annual weight gains and calculated summer productivities of 14 plants in 2 size classes that survived 1 complete yr in situ

\begin{tabular}{|c|c|c|c|c|c|c|c|}
\hline \multirow[b]{2}{*}{$\begin{array}{l}\text { Size } \\
\text { class }\end{array}$} & \multirow[b]{2}{*}{$\begin{array}{l}\text { Initial } \\
\text { frond } \\
\text { fresh } \\
\text { weight } \\
\text { (g) }\end{array}$} & \multicolumn{3}{|c|}{ Basal blade } & \multicolumn{3}{|c|}{ Whole plant } \\
\hline & & $\mathrm{N}$ & $\begin{array}{c}\text { Total } \\
\text { carbon } \\
(g)\end{array}$ & $\begin{array}{l}P: B \\
\text { ratio }\end{array}$ & $\begin{array}{l}\text { Net annual } \\
\text { carbon } \\
\text { production } \\
\qquad(g)\end{array}$ & $\begin{array}{l}\mathrm{P}: \mathrm{B} \\
\text { ratio }\end{array}$ & $\begin{array}{l}\text { Calculated summer } \\
\text { productivity } \\
\text { (means } \pm 95 \% \mathrm{CL}_{i} \\
\left.\mu \mathrm{g} \mathrm{C} \mathrm{mg}^{-1} \mathrm{~h}^{-1}\right)^{\mathrm{b}}\end{array}$ \\
\hline Small & $1-5$ & 6 & 0.467 & 1.7 & 0.355 & 1.3 & $0.119 \pm 0.022$ \\
\hline $\begin{array}{l}\text { Medium } \\
\text { B Based } \\
\text { barbon }\end{array}$ & $\begin{array}{l}7-15 \\
\text { of availa } \\
\text { on per } m\end{array}$ & $\begin{array}{l}\text { ght } \\
\text { we }\end{array}$ & $\begin{array}{l}1.063 \\
\text { ell et al. } \\
\text { of total su }\end{array}$ & 1.2 & 0.680 & 0.8 & $0.085 \pm 0.012$ \\
\hline
\end{tabular}


by 3 to $4 \%$ in both blades. The carbon content is replenished between late April and early August. This increase may not start until June, however, when breakup of the ice canopy begins. Elevated levels of carbon occur through the summer and autumn. Such a distinct seasonal pattern in carbon content has not previously been noted in kelp. Little seasonal variation in carbon content is reported for either Laminaria longicruris (Mann 1972) or Macrocystis pyrifera (Wheeler \& North 1981).

The presence of autumn or winter carbon deficit when irradiance is below the compensation point has also been observed for short periods in Laminaria longicruris (Hatcher et al. 1977) and apparently in L. saccharina as well (Johnston et al. 1977). Hatcher et al. found carbon assimilation was negative in November and that stored carbon was needed to support the growth of L. longicruris from October to early January. In $L$. saccharina, the question of a winter carbon deficit is more complicated since Johnston et al. (1977) believed that the carbon requirements for growth and respiration were met by light plus dark (LICF) fixation. This is difficult to accept for the same reasons outlined by Gagné et al. (1982); these include: (1) the Calvin cycle is the dominant pathway and the only lightdependent one for $\mathrm{CO}_{2}$ fixation in the Phaeophyta (Kremer 1981); and (2) a net gain of carbon by dark fixation is not possible without the input of energy (e.g. the glycolytic catabolism of reserve carbohydrate; Willenbrink et al. 1975, Kremer 1981). This is the basis for the subtraction of the dark fixation rate from total net photosynthetic ${ }^{14} \mathrm{C}$ uptake as originally prescribed by Steemann Nielsen (1952), but later questioned by Morris et al. (1971) before the pioneering work on LICF in brown algae had been completed by Akagawa et al. (1972).

If the correction for dark fixation is applied to the ${ }^{14} \mathrm{C}$ light fixation rates for Laminaria saccharina (Johnston et al. 1977), the respiratory requirement of the plant exceeds photosynthetic carbon assimilation for $3 \mathrm{mo}$ (November to January). The dependence of $L$. saccharina on stored photosynthate during this period is not clear, since Johnston et al. indicate that most reserves are lost via distal frond erosion in October and November.

With the exception of Laminaria hyperborea and $L$. solidungula, none of the laminarians studied to date appear to possess the traits necessary for sustained growth at light levels well below the compensation point for periods of 6 mo or longer. In both L. solidungula and L. hyperborea, cessation of linear growth occurs by early summer followed by storage of photosynthate as reflected in tissue densities of 24 to $27 \%$ (Lüning 1971, 1979, Dunton et al. 1982). While L. saccharina occurs alongside $L$. solidungula in the
Boulder Patch, it possesses a distinctly different pattern of growth that suggests an inability to use stored carbon reserves (Dunton 1985b). If such is the case, it may have important implications with respect to the current controversy regarding the role of genetic and environmental factors in regulating growth of Laminaria.

\section{Role of dark fixation}

It is now generally accepted that translocation plays a vital role in the growth of Laminaria spp., both for the transport of photosynthate to meristematic tissue during periods of rapid growth, and for the transport of stored materials for growth and metabolism when light is below the compensation point (Lüning et al. 1973, Hatcher et al. 1977, Johnston et al. 1977). Translocation is a common feature in the Laminariales, and all species studied so far possess a long-distance transport system in the medulla (Schmitz 1982). The composition of the translocate consists of high amounts of both amino acids and mannitol (Lüning et al. 1972).

In brown algae, the carboxylating enzyme of dark carbon assimilation is phosphoenolpyruvate carboxykinase (PEP-CK), yielding oxalacetate, aspartate and malate (Akagawa et al. 1972). The substrate of PEP$\mathrm{CK}$, phosphoenolpyruvate (PEP), is provided by an intermediate of the reductive pentose phosphate cycle in the light, and by glycolytic catabolism of reserve carbohydrate in the dark (Kremer 1981). Several workers have shown that, relative to photosynthetic assimilation, the rates of dark fixation and PEP-CK activity in the young growing parts of the frond are 4 to 5 times greater than in older portions (Willenbrink et al. 1975, 1979, Küppers \& Kremer 1978). In Laminaria solidungula, we found the relative rates of dark fixation greatest directly above the meristematic region, but these rates were obtained during the period of slowest tissue production. In all, dark fixation accounted for approximately $13 \%$ of the total carbon fixed in L. solidungula, compared to 13 to $85 \%$ in different regions of the thallus in L. hyperborea and 5 to $17 \%$ in L. saccharina (Küppers \& Kremer 1978).

Küppers \& Kremer (1978) found that the absolute amounts of nitrogenous compounds were highest in meristematic tissue where maximum activities of PEP$\mathrm{CK}$ and dark fixation were observed. In Laminaria solidungula, the highest $\mathrm{N}$ content and lowest $\mathrm{C}: \mathrm{N}$ ratio occur in the basal blade between February and April (Fig. 4). This corresponds to the period of rapid linear growth in $L$. solidungula and the occurrence of higher ambient inorganic nitrogen concentrations. But in this plant the higher concentrations of inorganic nitrogen $\left(3.3 \mu \mathrm{g}\right.$-at $\mathrm{l}^{-1}$ ) do not appear responsible for the recorded higher internal nitrogen levels. Chapman 
et al. (1978) found that an increase in external $\mathrm{NO}_{3}^{-}$ concentration from 0 to $3 \mu \mathrm{g}$-at $\mathrm{l}^{-1}$ only raised the total $\mathrm{N}$ content $0.15 \%$ and changed the $\mathrm{C} / \mathrm{N}$ ratio one integer in L. saccharina. Thus, L. solidungula appears to actively concentrate its nitrogen reserves in the young basal blade. Elevated concentrations of tissue $\mathrm{N}$ in actively growing regions of plant tissue have been noted by Wheeler \& North (1981). The coincidence of a high nitrogen content in young tissue constantly supplied with reduced material, such as mannitol, suggests that LICF may account for the vigorous growth that results in a net carbon deficit in L. solidungula during the dark ice-covered months.

\section{Carbon budget}

Most, if not all, of the carbon required by Laminaria solidungula to produce a new blade during the icecovered period is derived from food reserves in the second blade. Actual gains in carbon content via photosynthesis do not occur until late spring or early summer. But net summer carbon production, as estimated by ${ }^{14} \mathrm{C}$ uptake experiments, nearly matches the net annual carbon gain of experimental plants grown in situ, with little left over for winter respiration between November and February (photosynthetic carbon fixation due to some light penetration of the ice canopy appears almost to offset respiratory requirements after February; see Fig. 5). The carbon fixation rates reported here using ${ }^{14} \mathrm{C}$ uptake experiments $(0.08$

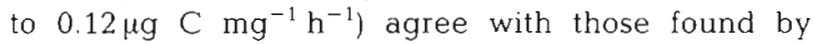
Küppers \& Kremer (1978) for L. hyperborea 10.08 to $0.2 \mu \mathrm{g} \mathrm{C} \mathrm{mg}^{-1} \mathrm{~h}^{-1}$ ). For $L$. saccharina, fixation rates

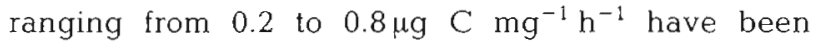
reported (Johnston \& Cook 1968, Johnston et al. 1977 , Küppers \& Kremer 1978).

Underestimating the number of hours available for summer photosynthesis probably accounts for most of the missing carbon needed to satisfy winter respiratory requirements. The number of hours used to calculate summer productivity in Table 4 is estimated for arctic phytoplankton (Schell et al. 1984) which are lightsaturated at about $200 \mu \mathrm{E} \mathrm{m}^{-2} \mathrm{~s}^{-1}$ (Platt et al. 1980). In contrast, Laminaria solidungula appears to be lightsaturated at much lower levels, about 40 to $60 \mu \mathrm{E}$ $\mathrm{m}^{-2} \mathrm{~s}^{-1}$ (Chapman \& Lindley 1980). For comparison, light saturation in L. saccharina off the coast of Scotland is about $120 \mu \mathrm{E} \mathrm{m}^{-2} \mathrm{~s}^{-1}$ (Johnston et al. 1977), $80 \mu \mathrm{E} \mathrm{m}^{-2} \mathrm{~s}^{-1}$ for L. hyperborea in the North Sea (Willenbrink et al. 1975), and about $40 \mu \mathrm{E} \mathrm{m}^{-2} \mathrm{~s}^{-1}$ in the giant kelp Macrocystis integrifolia and Nereocystis leutkeana off British Columbia (Willenbrink et al. 1979). In the Boulder Patch, the lowest mean hourly irradiances recorded daily in early to mid-August were
$40 \mu \mathrm{E} \mathrm{m}^{-2} \mathrm{~s}^{-1}$ (Table 3). This indicates L. solidungula was light-saturated nearly $24 \mathrm{~h}$ a day, although Schell et al. (1984) report only 20 photosynthetically useful hours per day in August. In September, only fifteen $12 \mathrm{~h}$ days are budgeted, although open water persists for nearly the whole month, and sometimes into October. If these light-rich hours are taken into account, the carbon available for winter respiration is increased considerably.

In contrast to the carbon budgets constructed for Laminaria longicruris (Hatcher et al. 1977) and L. SaCcharina (Johnston et al. 1977), L. solidungula does not possess an assimilatory surplus during a major portion of the year. Whereas both Hatcher and Johnston searched for an additional carbon sink to account for a carbon surplus for each species (about 25 to $35 \%$ of net annual productivityl, no such dilemma occurs in the case of $L$. solidungula. The release of dissolved organic matter by this plant must amount to a very small percentage of the total carbon fixed. In summary, the ability of $L$. solidungula to reallocate carbon reserves to survive over 8 mo of continuous darkness annually, and yet still replace $80 \%$ of its carbon content, should qualify it for a phycological commendation.

Acknowledgements. We are grateful to G. Cinkovich, J. Hanes, J. Olson and P. Plesha for diving assistance, and to S. Schonberg, V. Piekarski, D. Parrish, A. Paulson, J. Braddock and L. Flood for their help in the laboratory and in the final preparation of this manuscript. We thank R. T. Wilce for. his excellent criticisms of the manuscript and support of our arctic research on Laminaria. The constructive comments and criticisms by 3 anonymous referees are also greatly appreciated. This research was supported by a doctoral fellowship from the Office of the Vice Chancellor for Research and Advanced Study (University of Alaska-Fairbanks). Field support was provided by the Bureau of Land Management through an interagency agreement with the National Oceanic and Atmospheric Administration, under which a multiyear program responding to needs of petroleum development of the Alaskan Continental Shelf is managed by the Outer Continental Shelf Environmental Assessment Program (OCSEAP) office.

\section{LITERATURE CITED}

Akagawa, H., Ikawa, T., Nisizawa, K. (1972). ${ }^{14} \mathrm{CO}_{2}$-fixation in marine algae with special references to the dark-fixation in brown algae. Botanica mar. 15: 126-132

Chapman, A. R. O., Craigie, J. S. (1977). Seasonal growth in Laminaria longicruris: relations with dissolved inorganic nutrients and internal reserves of nitrogen. Mar. Biol. 40: 197-205

Chapman, A. R. O., Lindley, J. E. (1980). Seasonal growth of Laminaria solidungula in the Canadian High Arctic in relation to irradiance and dissolved nutrient concentrations. Mar. Biol. 57: 1-5

Chapman, A. R. O., Lindley, J. E. (1981). Productivity of Laminaria solidungula J. Ag. in the Canadian High Arc- 
tic: a year round study. In: Levring, $T$ (ed.) $X$ Internat Seaweed Symp. Proc., Walter de Gruyter, Berlin, p. $247-252$

Chapman, A. R. O., Markham, J. W., Lüning, K. (1978). Effects of nitrate concentration on the growth and physiology of Laminaria saccharina (Phaeophyta) in culture. J. Phycol. 14: 195-198

Dunton, K. H. (1984). An annual carbon budget for an arctic kelp community. In: Barnes, P. W., Schell, D., Reimnitz, E (ed.) The Alaskan Beaufort Sea: ecosystems and environments. Acad. Press, Orlando, p. 311-326

Dunton, K. H. (1985a). Trophic dynamics in marine nearshore systems of the Alaskan High Arctic. Ph. D. dissertation, Univ. Alaska, Fairbanks

Dunton, K. H. (1985b). Growth of dark-exposed Laminaria saccharina (L.) Lamour. and Laminaria solidungula J. Ag. (Laminariales, Phaeophyta) in the Alaskan Beaufort Sea. J. exp. mar. Biol. Ecol. 94: 181-189

Dunton, K. H., Reimnitz, E., Schonberg, S. (1982). An arctic kelp community in the Alaskan Beaufort Sea. Arctic 35: $465-484$

Gagné, J., Mann, K., Chapman, A. R. O. (1982). Seasonal patterns of growth and storage in Laminaria longicruris in relation to differing patterns of availability of nitrogen in the water. Mar. Biol. 69: 91-101

Hatcher, B. G., Chapman, A. R. O., Mann, K. H. (1977). An annual carbon budget for the kelp Laminaria longicruris. Mar. Biol. 44: 85-96

Johnston, C. S., Cook, J. P. (1968). A preliminary assessment of the techniques for measuring primary production in macrophytic marine algae. Experientia 24: 1176-1177

Johnston, C. S., Jones, R. G., Hunt, R. D. (1977). A seasonal carbon budget for a laminarian population in a Scottish sea-loch. Helgoländer Meeresunters. 30: 527-545

Kremer, B. P. (1981). Dark reactions of photosynthesis. In: Platt, T. (ed.) Physiological bases of phytoplankton ecology. Can. Bull. Fish. Aquat. Sci 210, p. 44-54

Küppers, U., Kremer, B. P. (1978). Longitudinal profiles of $\mathrm{CO}_{2}$-fixation capacities in marine macroalgae. Pl. Physiol. 62: $49-54$

Lüning, K. (1971). Seasonal growth of Laminaria hyperborea under recorded underwater light conditions near Helgoland. In: Crisp, D. J. (ed.) Proc. 4th European Mar. Biol. Symp. University Press, Cambridge, p. 347-361

Lüning, K. (1979). Growth strategies of three Laminaria species (Phaeophyceae) inhabiting different depth zones in the sublittoral region of Helgoland (North Sea). Mar. Ecol. Prog. Ser 1: 195-207

Lüning, K., Schmitz, K., Willenbrink, J. (1972). Translocation of ${ }^{14} \mathrm{C}$-labelled assimilates in two Laminaria species. Int. Seaweed Symp. 7: 420-425

Lüning, K., Schmitz, K., Willenbrink, J. (1973). CO flxation and translocation in benthic marine algae. III. Rates and ecological significance of translocation in Laminaria hyperborea and L. saccharina. Mar Biol. 23: 275-281

Mann, K. H. (1972). Ecological energetics of the seaweed zone in a marine bay on the Atlantic coast of Canada. II. Productivity of the seaweeds. Mar Biol 14: 199-209

Morris, I., Yentsch, C. M., Yentsch, C. S. (1971). Relationship between light carbon dioxide fixation and dark carbon dioxide fixation by marine algae. Limnol. Oceanogr. 16: $854-858$

Platt, T Gallegos, C. L., Harrison, W G. (1980). Photoinhibition of photosynthesis in natural assemblages of marine phytoplankton. J. mar. Res. 38: 687-701

Schell, D. M., Ziemann, P. J., Parrish, D. M., Dunton, K. H., Brown, E. J. (1984). Food web and nutrient dynamics in nearshore Alaska Beaufort Sea waters. In: Outer Continental Shelf Environmental Assessment Program, Final Report. National Oceanic and Atmospheric Administration, vol. 25, p. $327-499$

Schmitz, K. (1982). Translocation or organic compounds in Laminariales. In: Srivastava, L. M. (ed.) Synthetic and degradative processes in marine macrophytes. Walter de Gruyter, New York, p. 167-182

Steemann Nielsen, E. (1952). The use of radioactive carbon $\left(\mathrm{C}^{14}\right)$ for measuring organic production in the sea. J. Cons. perm. int. Explor. Mer 18: 117-140

Strickland, J. D. H., Parsons, T R. (1972). A practical handbook of seawater analysis. Bull. fish. Res. Bd Can. 167: $1-310$

Wheeler, P. S., North, W. J. (1981). Nitrogen supply, tissue composition and frond growth rates of Macrocystis pyrifera off the coast of southern California. Mar. Biol. 64: 59-69

Willenbrink, J., Kremer, B. P., Schmitz, K., Srivastava, L. M. (1979). Photosynthetic and light-independent carbon fixation in Macrocystis, Nereocystis, and some selected Pacific Laminariales. Can. J. Bot. 57 890-897

Willenbrink, J., Rangoni-Kübbeler, M., Tersky, B. (1975). Frond development and $\mathrm{CO}_{2}$-fixation in Laminaria hyperborea. Planta 125: 161-170 